\title{
The Density and Viability of Metarhizium anisopliae Conidia on Several Growth Media
}

\author{
Dyah Rini Indriyanti, Siti Harnina Bintari, Ning Setiati, Jamil Maulana Zahriyan Alfiyan \\ Department of Biology, Faculty of Mathematics and Natural Sciences, Universitas Negeri Semarang, Indonesia \\ *Corresponding Author: dyahrini36@gmail.com
}

Submitted: 2021-05-06. Revised: 2021-07-21. Accepted: 2021-08-13

\begin{abstract}
Metarhizium anisopliae is a parasitic fungus on insects, and thus called entomopathogenic fungus. This fungus is used as a biological control agent for insect pests. Fungal propagation can be done using a variety of media. The purpose of this study was to analyze the growth of M. anisopliae on four types of media, with conidial density and viability as the growth parameters. This research was conducted at the Laboratory of Microbiology, Universitas Negeri Semarang. This study was an experimental research used a Completely Randomized Design (CRD) with one factor and four treatments: Control (PDA/Potato Dextrose Agar medium), Treatment I (ELSA/Extract Larvae Sucrose Agar medium), Treatment II (CWSA/Coconut Water Sucrose Agar medium), Treatment III (CWELSA/Coconut Water and Extract Larvae Sucrose Agar medium). The and results showed that there was an effect of growth media on the density and viability of $M$. anisopliae conidia. CWELSA media had the highest conidial density $\left(2.91 \times 10^{8} \mathrm{cfu} / \mathrm{mL}\right)$ and viability (97.17\%). CWSA media had $2.82 \times 10^{8} \mathrm{cfu} / \mathrm{mL}$ and $95.33 \%$. PDA media had $2.25 \times 10^{8} \mathrm{cfu} / \mathrm{mL}$ and $92.83 \%$. ELSA media had $1.64 \mathrm{x}$ $10^{8} \mathrm{cfu} / \mathrm{mL}$ and $90.83 \%$. The high conidial density and viability of $M$. anisopliae is CWELSA medium. This study is as an alternative growth medium to improve the quality of $M$. anisopliae propagation.
\end{abstract}

Key words: Conidial density; Conidial viability; Growth medium; Metarhizium anisopliae

How to Cite: Indriyanti, D. R., Bintari, S. H., Setiati, N., \& Alfiyan, J. M. Z. (2021). The Density and Viability of Metarhizium anisopliae Conidia on Several Growth Media. Biosaintifika: Journal of Biology \& Biology Education, 13(2), 237-242.

DOI: http://dx.doi.org/10.15294/biosaintifika.v13i2.31408

\section{INTRODUCTION}

Entomopathogenic fungi have potential as biological agents for controlling pest infestation (Rai et al., 2014; Indriyanti et al., 2018a). The use of entomopathogenic fungi as biological agents is preferred because they have a high reproductive capacity, short life cycle, and able to form conidia that can survive in unfavorable environmental condition (Ibrahim et al., 2015). One of the entomopathogenic fungal species that can be used as biological controlling agent is Metarhizium anisopliae (Indriyanti et al., 2017). This entomopathogenic fungus has been known to be very effective in controlling several pest species. It has a wide range of insect hosts including Lepidotera, Coleoptera, Hemiptera, Diptera, and Hymenoptera (Moonjely \& Bidochka, 2019; Lovett et al., 2015).

However, repeated in vitro subculture in a medium can reduce the viability and virulence of entomopathogenic fungi (Hussain et al., 2010). The decreased entomopathogenic fungal spore quality can be caused by the reduced sources of carbon, chitin, starch, and protein in the culture medium (Herlinda et al., 2006; Ansari \& Butt, 2011). Medium has an important role as a place for microorganisms to grow. In addition to grow microorganisms, the medium can be used for isolation and propagation as well as for testing their physiological properties and calculating the the number of microorganism (Nuryanti et al., 2012).

Growth medium for entomopathogenic fungi must contain organic compounds as a source of carbon, nitrogen, inorganic ions, and vitamins in sufficient quantities to support the fungal growth (Liu et al., 2018). The formation of fungal conidia is influenced by the protein content of the medium (Shah et al., 2005). Protein is needed for organelle and hyphal formation as well as for enzyme synthesis and germination (Rohman et al., 2017). Protein is absorbed by the fungus in the form of amino acids. The virulence and pathogenicity of entomopathogenic fungi are also influenced by the addition of chitin as a carbon and nitrogen source (Senthiraja et al., 2010). The addition of chitin in culture media can induce the production of chitinase that play a role in maintaining the infectivity of entomopathogenic fungi (Nahar et al., 2004).

M. anisopliae can infect and grow in Oryctes rhinoceros larvae (Indriyanti et al., 2018b) Larvae powder is rich in chitin and protein that can increase the number of infective conidia as well as their virulence against the pests (Prayogo et al,. 2017; Pramesti et al., 2014). The medium commonly used in the laboratory is Potato Dextrose Agar (PDA). In order to improve the growth quality, it is necessary to add materials derived from insect body parts as well as other nutrients. The addition of $O$. rhinoceros 
larvae on PDA media was expected to improve the growth of the fungi since $M$. anisopliae grew well on $O$. rhinoceros larvae. Another material that is rich in nutrition is coconut water, it contains a complete composition to meet nutritional needs in growth media. Coconut water contains substances such as nutrients, vitamins, amino acids, nucleic acids, and growth substances such as auxin and gibberellic acid which function as stimulants for tissue proliferation and facilitate metabolism and respiration (Prando et al., 2014). The use of coconut water in the growth medium of $M$. anisopliae also has the potential to increase the viability, density, and pathogenicity of the M. anisopliae fungus (Sambiran \& Hosang, 2007).

Based on the problem that has been described, it is necessary to determine the effective composition of coconut water and larvae powder in the growth medium of $M$. anisopliae to increase the density and viability of their conidia. The purpose of this study was to analyze the most effective growth medium for of $M$. anisopliae. The benefit of this study is as an alternative growth medium to improve the quality of M. anisopliae propagation

\section{METHODS}

\section{M. anisopliae isolate}

M. anisopliae isolates obtained from the Laboraroty of BPTPHP Salatiga, Central Java were purified on PDA medium with agar plate method in the petri dishes. The isolates were then incubated at room temperature $25^{0} \mathrm{C}$ for 21 hours. This study was conducted at the Microbiology Laboratory, Biology Department, Universitas Negeri Semarang.

\section{O. rhinoceros larvae powder processing}

The larvae of $O$. rhinoceros were killed by immersing them in boiling water for 1 minute. They were then oven-dried at $65^{\circ} \mathrm{C}$. Dried larvae were ground to obtain larvae powder.

\section{Composition of culture media}

There were four types of media used in this study with compositions as follows:

1. PDA ( $88 \%$ concentrated potato extract $20 \%$ concentration $+10 \%$ sugar $+2 \%$ agar)

2. ELSA ( $1 \%$ extract of $O$. rhinoceros larvae powder $10 \%$ concentration $+87 \%$ distilled water $+10 \%$ sugar $+2 \%$ agar)

3. CWSA $(88 \%$ coconut water $+10 \%$ sugar $+2 \%$ agar)

4. CWELSA ( $1 \%$ extract of $O$. rhinoceros larvae powder $10 \%$ concentration $+87 \%$ coconut water $+10 \%$ sugar $+2 \%$ agar)
All the media were sterilized in an autoclave at 1.5 atm with a temperature of $121^{\circ} \mathrm{C}$ for 25 minutes.

\section{M. anisopliae inoculation}

Inoculation of $M$. anisopliae $\left(100 \mu \mathrm{l}\right.$ diluted to $\left.10^{-6}\right)$ on each medium used the spread plate technique. The isolates were inoculated and spread onto the media using drigalski spatula in a sterile condition. The petri dishes were then sealed, labelled, and kept in incubator at $\pm 25-28{ }^{\circ} \mathrm{C}$ for 4 days.

\section{Calculation of conidial density and viability}

Conidial density was counted on the $4^{\text {th }}$ day after inoculation using Total Plate Count technique. This calculation assumes that every single cell that grows will grow into a colony. In addition, it is also based on the Standard Plate Count. The formula used is as follows:

Conidial density $=$ number of colony $\mathrm{x} \frac{1}{\text { dilution factor }}$

Calculation of conidial viability was performed on the slide culture at 24 hours after inoculation. Viability of the conidia was calculated using the following formula:

$V=\frac{g}{g+u} \times 100 \%$

Note:

$\mathrm{V}=$ conidial viability

$\mathrm{g}=$ number of germinated conidia

$\mathrm{u}=$ number of non-germinated conidia

\section{Statistical analysis}

This study used Completely Randomized Design with six repetitions and four treatments: Control (PDA medium), Treatment 1 (ELSA/Extract Larvae Sucrose Agar medium), Treatment II (CWSA/ Coconut Water Sucrose Agar medium), Treatment III (CWELSA/Coconut Water and Extract Larvae Sucrose Agar medium).

The independent variable of this study was the media composition, while the dependent variables were density and viability of conidia. The number of conidial density and the percentage of conidial viability were tested for their normality (ShapiroWilk) and homogeneity. The data were then analyzed using One Way ANOVA followed by Tukey's HSD test for significantly different results.

\section{RESULTS \& DISCUSSION}

\section{Conidial density of M. anisopliae}

The results of conidial density calculation and further analysis with Tukey's HSD test are presented in Table 1. 
Table 1. Conidial density of Metarhizium anisopliae on growth medium

\begin{tabular}{lc}
\hline Medium & Average conidial density $\left(\times 10^{8} \mathrm{cfu} / \mathrm{mL}\right)$ \\
\hline CWELSA & $2.91^{\mathrm{a}}$ \\
CWSA & $2.82^{\mathrm{a}}$ \\
PDA & $2.25^{\mathrm{b}}$ \\
ELSA & $1.64^{\mathrm{c}}$ \\
\hline
\end{tabular}

${ }^{*}$ Numbers in the same column followed by the same letter are not significantly different at the 5\% significance level in the Tukey's test; ${ }^{*)} \mathrm{cfu} / \mathrm{ml}=$ Colony forming unit per mililiter

The results of the One Way ANOVA analysis at the $5 \%$ level obtained the Sig. value of $0.00<0.050$, so that there was an influence of growth media on the number of $M$. anisopliae conidial density. Tukey's HSD analysis showed that CWELSA and CWSA medium had the highest effectiveness compared to ELSA and PDA (control) on the conidial density of $M$. anisopliae. CWELSA and CWSA medium did not differ significantly based on Tukey's analysis, so it was concluded that both media had the same effect on

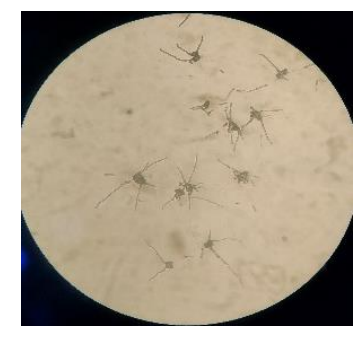

PDA medium

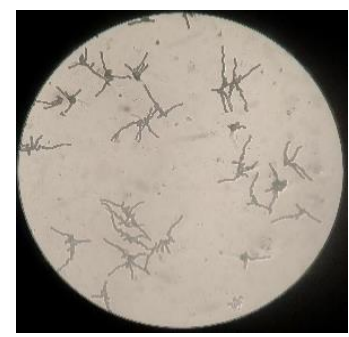

ELSA medium

the conidial density. Based on BPTPHP standard, a good conidial density is more than $10^{6} \mathrm{cfu} / \mathrm{mL}$ (BPTBUN, 2011). The results showed a good density with the number of conidia of $10^{8} \mathrm{cfu} / \mathrm{mL}$ in each growth medium.

\section{M. anisopliae conidial viability}

The results of conidial viability calculation and further analysis with Tukey's HSD test is presented in Table 2.

Table 2. Conidial viability of $M$. anisopliae on growth medium

\begin{tabular}{lc}
\hline Medium & Average conidial viability (\%) \\
\hline CWELSA & $97.17^{\mathrm{a}}$ \\
CWSA & $95.33^{\mathrm{a}}$ \\
PDA & $92.83^{\mathbf{b}}$ \\
ELSA & $90.82^{\mathbf{b}}$ \\
\hline
\end{tabular}

${ }^{*}$ Numbers in the same column followed by the same letter are not significantly different at the 5\% significance level in the Tukey's test

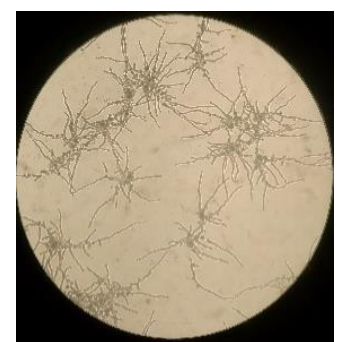

CWSA medium

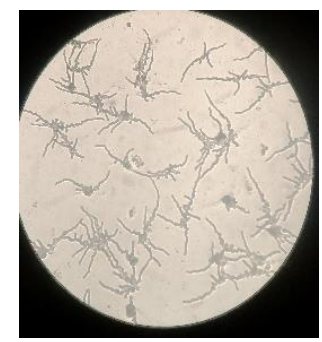

CWELSA medium

Figure 1. Conidial viability of $M$. anisopliae observed at 24 hours after inoculation with 10x10 magnification on the growth media

The result show (Tabel 1 and Tabel 2) that the highest conidial density and viability was CWELSA medium, and the lowest was ELSA medium. ELSA growth medium showed the lowest conidial density compared to CWELSA, CWSA, and PDA control medium. It is because in the preparation of $O$. rhinoceros larvae powder, the insect went through several stages of drying, so that there was a decrease or degradation of protein and chitin. The use of larvae powder extract in low concentrations causes low condial density. Sucrose was used in the ELSA medium because it has disaccharide sugar structure that requires a hydrolysis process by fungi for use in metabolism, while the dextrose sugar in PDA medium has a simple monosaccharide sugar structure that can be directly absorbed for metabolic processes. According to Aryo et al. (2017), disaccharide sugars go through a hydrolysis stage before being used for energy metabolism. This is in accordance with the results of the study that the PDA medium (dextrose sugar) showed a higher conidial density than the ELSA medium (sucrose sugar).

The nutritional content in larvae powder extract on ELSA medium is protein and chitin. This is in accordance with Herlinda et al. (2006) that nutritional content in media made from larvae is dominated by protein and chitin. Entomopathogenic fungi require more complex nutrients to fulfill their nutritional needs. According to Liu et al. (2018) the growing media for entomopathogenic fungi must contain organic substances such as a carbon, nitrogen, inorganic ions, and vitamins. According to Novianti (2017), the nutrients contained in the growing media greatly affect the density of conidia. This is in accordance with the results of the study that protein and chitin contained in the ELSA medium were insufficient to meet the nutritional needs of the $M$. anisopliae, resulting in a low conidial density.

PDA medium showed a higher conidial density than ELSA, but lower than CWSA and CWELSA 
medium. PDA is a growth medium that is often used to multiply fungi in the laboratory. It is related to the nutrients contained in the PDA medium such as carbohydrates, protein, phosphorus, and water. PDA medium also contains the simple sugar dextrose and vitamins. This condition supports the condial density of PDA medium to be higher than that of ELSA medium. The conidial density of PDA medium was lower than that of coconut water-based media (CWSA and CWELSA). Media made from coconut water had more complete nutrition when compared to PDA medium. In addition, the macro elements contained in coconut water have a higher concentration when compared to medium made from potato extract. Saidah (2005) stated that the media made from coconut water contains monosaccharide sugar, protein, carbohydrates, amino acids (aspartate, glutamate, serine and lysine), vitamins (ascorbic acid, thiamine, and folic acid), macro and micro minerals, and growth substances. This is in accordance with the results of the study that the conidial densities on CWSA and CWELSA media were higher than that of on PDA medium.

Based on the Tukey's HSD test, the conidial densities on CWSA and CWELSA media were not significantly different. This means that both media have the same effect on the conidial density of $M$. anisopliae. CWSA and CWELSA media are media made from coconut water, the difference between these two media is that in CWELSA medium the extract of $O$. rhinoceros larvae powder was added. The average conidial density of CWELSA medium was higher than that of CWSA medium (Table 1). This was due to the addition of larvae powder extract which increased the concentration of chitin and protein in CWELSA medium. The two media were not significantly different due to the low level of larvae powder extract used (1\%). The use of larvae powder which was prepared through several drying processes is possible to decrease and degrade the nutrients contained in the extract.

CWELSA medium contained simple sugars, macro and micro minerals, protein, chitin, nitrogen, and organic substances. The extract of larvae powder on CWELSA medium provided additional nutrients of chitin and protein for the growth of entomopathogenic fungi. This is in accordance with the opinion of Nuryanti et al. (2012) that nutritional fulfillment of entomopathogenic fungi generally requires sugar in the form of monosaccharides as a carbon source, and several nutritional components, such as protein, nitrogen, and inorganic ions $\left(\mathrm{Mg}^{2+}\right.$ and $\mathrm{Ca}^{2+}$ ) to support the growth and reproduction of entomopathogenic fungi. The nutrients contained in the CWELSA medium were able to meet the growth requirements for the fungus $M$. anisopliae which indicated by a higher conidial density than others.

Carbon is needed in the metabolic process of entomopathogenic fungi. According to Puspaningrum \& Suparti (2013), carbon sourced from monosaccharide sugars is used as an energy source for metabolism (anabolism and catabolism) and is also needed in the form of pentose sugars as a component of nucleic acids that play a role in regulatory processes and gene expression through the process of protein biosynthesis and cell division.

Protein and chitin are needed in the formation of conidia and hyphae and increase the virulence of the fungus M. anisopliae. According to Liu et al. (2018), protein is needed in the formation of organelles that play a role in the formation of hyphae and the process of enzyme synthesis. Protein acts as a constituent of cell walls of entomopathogenic fungi (glycoproteins) as well as other compounds such as chitin, fat, and some inorganic ions. According to Herlinda et al. (2006), the addition of chitin to the growth media stimulates the production of chitinase which functions in maintaining the ability of entomopathogenic fungal infection.

Nitrogen content is needed in stimulating the growth and protein synthesis process of the $M$. anisopliae entomopathogenic fungus. According to Kalsum et al. (2011), nitrogen is needed in synthesizing purines and pyrimidines which are components of RNA and DNA that play a role in protein synthesis and cell division, it also stimulates the shoot growth in the asexual reproduction phase of entomopathogenic fungi. The inorganic ions $\left(\mathrm{Mg}^{2+}\right.$ and $\mathrm{Ca}^{2+}$ ) contained in the coconut water-based media play a role in stimulating the growth of $M$. anisopliae. $\mathrm{Ca}^{2+}$ ion plays a role in cell elongation and division, regulate membrane permeability and stability, provide cell integrity and strengthen the cell walls. The $\mathrm{Mg}^{2+}$ ion acts as a cofactor in protein synthesis and plays a role in the process of cell growth and tissue maintenance.

The recommended growth media composition for M. anisopliae is CWSA (Coconut Water Sucrose Agar) medium. It is because the preparation of CWSA medium is easier and more inexpensive compared to CWELSA medium. Treatment using CWSA medium was proven to provide a conidial density that was not significantly different compared to CWELSA medium.

Conidial density is related to the growth of the $M$. anisopliae colonies. One of the growth parameters that can be seen macroscopically is colony color. The color of the colony was initially white but after a few days it turned to green as they underwent maturation process. Conidial formation was faster in CWSA and CWELSA treatments compared to PDA. $M$. 
anisopliae with green/yellow color became dark green with zones. Conidia were formed after 1 week of growth, they were initially white and turned green after maturation. The process of maturation and cell propagation of the $M$. anisopliae requires nutrients so that the nutritional needs are very vital in the growth process of M. anisopliae.

The CWSA medium was able to produce high conidial viability by $95.55 \%$ that was not significantly different compared to CWELSA medium $(97.17 \%)$. This is in accordance with the hypothesis that the combination of media made from coconut water and larvae flour extract will produce high viability, eventhough the combination of the two materials was not resulted in a significant different result. Based on the explanation before, CWSA is the effective medium to provide a high conidial viability of M. anisopliae. Based on the standard of BPTPHP Salatiga, the good conidial viability is above $80 \%$ (BPTBUN, 2011). The results of this study showed conidial viability of more than $80 \%$ in each growth medium of $M$. anisopliae. Conidial viability is closely related to the nutrient content of each growth medium. According to Novianti (2017), nutrient sources are the determinants of growth, germination rate, and the viability of the fungus. The role of the growth medium greatly affects the viability of conidia, this is in accordance with the results of the study that show that the growth medium affects the viability of the conidia of $M$. anisopliae.

The viability of conidia in ELSA and PDA medium were lower than that in CWSA and CWELSA medium. It is because the nutrient content of the ELSA and PDA media is not as complete as the CWSA and CWELSA media. The nutritional content in the ELSA medium was dominated by protein and chitin. Entomopathogenic fungi require more complete nutrients such as nitrogen, amino acids, vitamins, macro and micro minerals, water, and growth substances. Germination process of fertile conidia requires inorganic ions such as $\mathrm{Mg}^{2+}$ and $\mathrm{Ca}^{2+}$. The incomplete nutrient content in ELSA medium affected the percentage of conidial viability, which was lower than the PDA, CWSA, and CWELSA media.

PDA medium provided lower conidial viability compared to CWSA and CWELSA medium. The PDA medium contains carbohydrates, protein, fat, phosphorus, iron, vitamins, and water. CWSA and CWELSA media produce higher conidial viability because they have more complete nutrients. According to Saidah (2005), media made from coconut water contains monosaccharide sugar, protein, carbohydrates, amino acids (aspartate, glutamate, serine and lysine), vitamins (ascorbic acid, thiamine, and folic acid), macro and micro minerals, and growth substances. This is in accordance with the results of the study that the viabilities of conidia on the CWSA and CWELSA media were higher than that of the PDA control medium. The high conidial density and viability of $M$. anisopliae is CWELSA medium. This study is as an alternative growth medium to improve the quality of $M$. anisopliae propagation

\section{CONCLUSION}

The composition of the growth medium affects the density and viability of $M$. anisopliae conidia. CWELSA and CWSA media are more effective than ELSA and PDA media. The high conidial density and viability of $M$. anisopliae is CWELSA (Coconut Water and Extract Larvae Sucrose Agar) medium.

\section{ACKNOWLEDGEMENT}

Researchers would like Gratitude to The DRPM, Jakarta for the Funding This Research Grant With Research Contract Number 30.14.7/Un37/Ppk.6.8/ 2021 Dated 14 July 2021.

\section{REFERENCES}

Ansari, M.A \& Butt, T.M. (2011). Effects of successive subculturing on stability, virulence, conidial yield, germination and shelf-life of entomopathogenic fungi. Journal of Applied Microbiology 110, 1460-1469.

Aryo, K., Purnomo., Wibowo, L., \& Aeny, T. N. (2017). Virulensi Beberapa Isolat Metarhizium anisopliae Terhadap Ulat Grayak (Spodoptera litura $F$ ) di Laboratorium. Jurnal Agrotek Tropika, 5(2), 96-101.

BPTBUN. 2011. Instructions for breeding and use of the Beauveria bassiana. By Estate Crop Protection Board in Salatiga, Central Java Province, Indonesia.

Herlinda, S., Utama, M.D., Pujiastuti, Y \& Suwandi. (2006). Kerapatan dan Viabilitas Spora Beauveria bassiana (Bals.) Akibat Subkultur dan Pengkayaan Media, Serta Virulensinya terhadap Larva Plutella xylostella (Linn.). Jurnal HPT Tropika 6(2): 70-78

Hussain, A., Ming-Yi Tian, Yu-Rong He, Lin Ruan, L \& Ahmed, S. (2010). In vitro and in vivo culturing impacts on the virulence characteristics of serially passed entomopathogenic fungi. Journal of Food, Agriculture \& Environment 8 (3\&4): 481-487.

Ibrahim, L., Laham, L., Touma, A \& Ibrahim, S. (2015). Mass Production, Yield, Quality, Formulation and Efficacy of Entomopathogenic 
Metarhizium anisopliae Conidia. British Journal of Applied Science \& Technology 9(5): 427-440.

Indriyanti, D. R., Damayanti, I. B., Setiani, N \& Maretta, Y. A. 2018a. Mortality and Tissue Damage of Oryctes rhinoceros Larvae Infected by Metarhizium anisopliae. ARPN Journal of Engineering and Applied Sciences 13(6): 2279 2286

Indriyanti, D. R., Rahmawati, R., Priyono, B., Slamet, M., \& Huyop, F. Z. 2018a. Ecological Studies of Oryctes rhinoceros Larvae Controlled by Metarhizium anisopliae and Entomopathogenic Nematodes. Jurnal Pendidikan IPA Indonesia 7 (3): 286-292

Indriyanti, D.R., Widyadningrum, P., Haryuni., Slamet, M., \& Maretta, Y.A. 2017. Effectivinees of Metahizium anisopliae and Entomopathogenic Nematodes to Control Oryctes rhinoceros Larvae in the Rainy Season. Pakistan Journal of Biological Science 20 (7): 320-327

Kalsum, U., Fatimah, S \& Wasonowati, C. 2011. Efektifitas Pemberian Air Leri Terhadap Pertumbuhan dan Hasil Jamur Tiram Putih (Pluerotus ostreatus). Jurnal Agrovitor 4(2): 86 92.

Liu, F., Xiang, M., Guo, Y., Wu, X., Lu, G., Yang, Y. (2018). Culture conditions and nutrition requirements for the mycelial growth of Isaria farinosa (Hypocreales: Cordycipitaceae) and the altitude effect on its growth and metabolome. Sci Rep 8, 15623 (2018).

Lovett, B., Raymond J. St. Leger. (2015). Stress is the rule rather than the exception for Metarhizium. Curr Genet (2015) 61:253-261.

Moonjely, S \& Bidochka, M.J. 2019. Generalist and specialist Metarhizium insect pathogens retain ancestral ability to colonize plant roots. Fungal Ecology 41 (2019) 209-217.

Nahar, P., Ghormade,V and Mukund V. Deshpande. (2004). The extracellular constitutive production of chitin deacetylase in Metarhizium anisopliae: possible edge to entomopathogenic fungi in the biological control of insect pests. Journal of Invertebrate Pathology 85 (2004) 80-88

Novianti, D. (2017). Efektifitas Beberapa Media Untuk Perbanyakan Cendawan Metarhizium anisopliae. Sainmatika Jurnal 14(2): $81-88$

Nuryanti, N. S. P., Lestari, W \& Abdul, A. (2012). Penambahan Beberapa Jenis Bahan Nutrisi Pada Media Perbanyakan Untuk Meningkatkan
Virulensi Beauveria bassiana Terhadap Hama Walang Sangit. Jurnal HPT Tropika 12(01): 64-70 Pramesti, N. R., Himawan, T \& Rachmawati, R. (2014). Pengaruh Pengkayaan Media dan Suhu Penyimpanan Terhadap Kerapatan dan Viabilitas Konidia Cendawan Patogen Serangga Beauveria bassiana (Balsamo) Vuillemin (Hypocreales: Cordypitaceae). Jurnal HPT 2(3): 42-50

Prando, MAS., P. Chiavazza, A. Faggio, C. Contessa. 2014. Effect of coconut water and growth regulator supplements on in vitro propagation of Corylus avellana L. Scientia Horticulturae 171 (2014): 91-94.

Prayogo, Y., Afandi, A., Puspitarini, R. D., \& Rachmawati, R. (2017). Penambahan Senyawa Kitin Untuk Meningkatkan Virulensi Cendawan Entomopatogen Beauveria bassiana dalam Membunuh Serangga Hama. Buletin Palawija 15(1), 31-43

Puspaningrum, I \& Suparti. (2013). Produksi Jamur Tiram Putih (Plurotus ostreatus) Pada Media Tambahan Molase dengan Dosis yang berbeda. Seminar Nasional X Pendidikan Biologi FKIP UNS, Surakarta.

Rai, D., V. Updhyay, V., Mehra, P., Rana, M. and Pandey, A.K. (2014). Potential Of Entomopathogenic Fungi as Biopesticides. Ind. $J$. Sci. Res. and Tech. 2014 2(5):7-13.

Rohman, F.L., Saputro, T.B., \& Prayogo, Y. (2017). Pengaruh Penambahan Senyawa Berbasis Kitin terhadap Pertumbuhan Cendawan Entomopatogen Beauveria bassiana. Jurnal Sains dan Seni ITS 6(2) : 13-16.

Saidah, R. (2005). Pengaruh Ekstrak Kelapa Muda Terhadap Pertumbuhan Akar Stek Melati (Jasminum sambac W. Ait). Malang UIN Malang.

Sambiran, W. J \& Hosang, M. L. A. (2007). Patogenitas Metharizium anisopliae dari Beberapa Media Air Kelapa Terhadap Oryctes rhinoceros L. Buletin Palma 32: 1-9

Senthiraja, G., Ariand, T., Durairaj, C., Raguchander, T., \& Samitappan, R. 2010. Chitin-based bioformulation of Beauveria bassiana and Pseudomonas fluorescens for improved control of leafminer and collar rot in groundnut. Crop Protec Jurnal 29(9) :1003-1010

Shah, FA., Cheng S. Wang, Tariq M. Butt. (2005). Nutrition influences growth and virulence of the insect-pathogenic fungus Metarhizium anisopliae. FEMS Microbiology Letters. 251 (2): 259-266. 